\title{
Long-Term Effects of Fire, Livestock Herbivory Removal, and Weather Variability in Texas Semiarid Savanna
}

\author{
Charles A. Taylor, Jr., ${ }^{1}$ Dirac Twidwell, ${ }^{2}$ Nick E. Garza, ${ }^{3}$ Colin Rosser, ${ }^{4}$ \\ James K. Hoffman, ${ }^{5}$ and Terry D. Brooks ${ }^{3}$
}

Authors are ${ }^{1}$ Regent Fellow and Professor, ${ }^{3}$ Research Associate, and ${ }^{4}$ Research Assistant, Texas A\&M University, Texas A $M$ Agrilife Research Center, Sonora, TX 76950, USA; and ${ }^{2}$ Instructor and Tom Slick Graduate Fellow and ${ }^{5}$ Undergraduate Research Assistant, Texas A\&M University, Department of Ecosystem Science and Management, College Station, TX 77843, USA.

\begin{abstract}
We examined how the occurrence and structure of grasses and woody plants changed after $12 \mathrm{yr}$ of a fire season manipulation and removal of livestock herbivores. Applying high intensity fires in the summer preserved the structural integrity of this semiarid live oak (Quercus virginiana Mill.) savanna while decreasing or eliminating numerous problematic plants in the understory and overstory, such as prickly pear cactus (Opuntia spp.), sacahuista (Nolina texana S. Watson), Ashe juniper (Juniperus ashei J. Buchholz), Pinchot's juniper (J. pinchotii Sudw.), and honey mesquite (Prosopis glandulosa Torr.). In the less intense repeat winter burning treatments, undesirable woody plants were generally maintained at pretreatment levels in the overstory but all woody plants except Ashe juniper increased in the understory. Alternatively, areas excluded from fire in the control treatment rapidly transitioned from a grass-tree codominated savanna environment to one that is heavily dominated by woody plants. In the grass community, the most frequently occurring grass species in the winter burn treatment differed from summer burn and control treatments, whereas the summer burn treatment was not different from the control. Of the herbaceous plants, only little bluestem (Schizachyrium scoparium [Michx.] Nash) responded to fire treatments. Little bluestem increased in the winter burn treatment, remained fairly constant in the summer burn treatment, and decreased in the control. Other grasses varied largely as a function of annual weather variability, the removal of livestock, and legacy effects resulting from pre-existing variability. These findings suggest that fire can reduce or eliminate woody plant species that threaten the stability of live oak savannas while having little long-term effect on grasses desired by rangeland managers.
\end{abstract}

\section{Resumen}

Examinamos el cambio que hubo en la ocurrencia y estructura de gramíneas y plantas leñosas después de 12 años de manipulación de la época del fuego y exclusión del pastoreo por el ganado. Por medio de la aplicación de alta intensidad de fuego durante el verano se preservó la integridad estructural de estas sabanas semiáridas de encino (Quercus virginiana Mill.) mientras decrecieron o se eliminaron una gran cantidad de plantas problemáticas que se ubican arriba y abajo de la cobertura arbórea, tales como especies de nopales (Opuntia spp.), sacahuista (Nolina texana S. Watson), Ashe juniper (Juniperus ashei J. Buchholz), Pinchot's juniper (J. pinchotii Sudw.), y mezquite (Prosopis glandulosa Torr.). En las áreas tratadas con fuegos de menor intensidad y repetidamente durante el invierno, las plantas leñosas indeseables se mantuvieron generalmente en niveles existentes a antes de la aplicación de las quemas en la cobertura aérea, pero todas las plantas leñosas excepto Ashe juniper se incrementaron en los lugares debajo de los árboles. Por otra parte, las áreas excluidas del fuego en los tratamientos que se usaron como controles cambiaron rápidamente pasando de ambientes dominados por pastos-árboles y co-dominados por sabanas a lugares que fueron altamente dominados por plantas leñosas. En la comunidad de pastos, las especies que se hallaron con mayor frecuencia en las quemas de invierno fueron diferentes de las plantas que se encontraron en las áreas que se quemaron durante el verano así como de las áreas usadas como control. Además, los tratamientos del fuego aplicados en el verano no fueron diferentes de los controles. Con respecto a las plantas herbáceas sólo little bluestem (Schizachyrium scoparium [Michx.] Nash) respondió a las quemas. Little bluestem se incrementó en áreas tratadas con fuego en el invierno, permaneció bastante constante en las áreas donde el fuego fue aplicado durante el verano y decreció en los controles. Otras especies de gramíneas variaron en gran medida como una función de la variabilidad del clima anual, la eliminación de ganado y los efectos heredados de variabilidad preexistente. Estos resultados sugieren que el fuego puede reducir o eliminar especies de plantas leñosas que son una amenaza para la estabilidad de sabanas de encino (live oak) ejercitando un pequeño efecto a largo plazo en los pastos más deseados por los manejadores de pastizales.

Key Words: grass, live-oak, occurrence, structure, woody plants

\section{INTRODUCTION}

Research was supported by Texas A\&M Agrilife Research, US Department of Agriculture Natural Resource Conservation Service (Conservation Innovation grant 68-3A75-5-180); Tom Slick Foundation; and Welder Wildlife Foundation (publication no. 702).

Correspondence: Dirac Twidwell, Texas A\&M University, Department of Ecosystem Science and Management, 2138 TAMU, College Station, TX 77803, USA. Email: dirac@tamu.edu

Manuscript received 30 July 2010; manuscript accepted 10 September 2011.
Semiarid savannas once covered more than $10 \%$ of the global land surface (Scholes and Walker 1993) but many are transitioning away from the grass-tree codominance that long characterized these ecosystems toward economically and aesthetically less desirable shrub-dominated woodlands (Hobbs and Mooney 1986; Trollope et al. 1989; Archer 1995; Silva 
et al. 2001; Brook and Bowman 2006). Such changes have been linked to problematic or invasive plant species, climate change, and human-induced alteration of top-down (e.g., fire, herbivory) and bottom-up (e.g., water, nutrients) controls (Johnson 1993; Scholes and Archer 1997; Bachelet et al. 2001; Bond and Midgley 2001; Bond 2008). Understanding the relative contributions and interactions among these causal drivers is therefore essential if rangeland managers are to maintain the desired proportion of grasses and trees that are essential to rangeland enterprises, livestock operations, and a variety of unique plant and animal species in semiarid environments.

Fire is an important top-down determinant of woody plant densities in many semiarid savannas (Scholes and Archer 1997; Bond et al. 2003; Sakranan 2004; Sakranan 2005; Higgins et al. 2007), but human-induced alteration of other top-down controls has resulted in extensive changes to fire regimes in semiarid regions (Scholes and Archer 1997). In particular, the global expansion of the cattle industry has led to unfavorable changes in fire-related feedbacks that maintain savanna (Van Vegten 1983). Overstocking with cattle over long periods has enabled problematic woody plant species to invade by reducing fine fuel load, fire intensity, and fire effects on woody plant species (Scholes and Archer 1997; Roques et al. 2001; Van Langevelde et al. 2003; Archibald et al. 2005). Moreover, expansion of the cattle industry to new regions has led to widespread displacement of domestic and native browsers (e.g., goats) that are remarkably effective at maintaining the density and structure of semiarid savanna when used in combination with fire (Trollope 1974; Higgins et al. 2000; Staver et al. 2009). As a result of the widespread reductions in grassland fuel loading, continuity, and fire intensity, heavy grazing with cattle has been implicated as the primary facilitating driver of woody plant encroachment in grassland and increased densities in savannas (Van Langevelde et al. 2003; Briggs et al. 2005).

Numerous woody plants are invading or causing other problems on the Edwards Plateau region of Texas. Sacahuista (Nolina texana S. Watson), while not particularly invasive, is a toxic subshrub that can be life-threatening to cattle, sheep, and especially goats (Merrill and Schuster 1978; Taylor and Ralphs 1992). Prickly pear cactus (Opuntia spp.) can form dense thickets, limiting livestock movement, reducing herbaceous production, and displacing native grasses (Freeman 1992; Lotter and Hoffman 1998). Ashe juniper (Juniperus ashei J. Buchholz), Pinchot's juniper (J. pinchotii Sudw.), and honey mesquite (Prosopis glandulosa Torr.) are notorious for their ability to rapidly invade grasslands and savannas in the absence of fire (Archer et al. 1988; Van Auken 2000).

This article presents the findings from an ongoing, long-term comparison of the effects of fire in different seasons on semiarid savanna vegetation in the Edwards Plateau. Fire treatments were ignited in fire weather and fuel conditions that maximized fire intensity. Fires were conducted in the summer and winter every $6 \mathrm{yr}$, on average, to match the estimated historical fire frequency of the region (Frost 1998) and to allow maximum fine fuel accumulation. Fire season is used as a proxy for fire intensity in this study since summer fires were specifically conducted in drought conditions to promote high intensity fires and maximize mortality of nonresprouting woody plants. Our objective is to determine if conducting fires during droughts in the growing season creates a different savanna community when livestock herbivory is excluded than burning in the winter or not burning.

\section{METHODS}

\section{Study Area}

This research was conducted in the Edwards Plateau ecological region on the Texas AgriLife Research Station (lat $31^{\circ} \mathrm{N}$, long $\left.100^{\circ} \mathrm{W}\right)$ located $56 \mathrm{~km}$ south of Sonora, Texas. This site features gently rolling topography on soils of the Tarrant silty clay series, which are members of the clayey-skeletal, montmorillonitic, thermic family of Lithic Haplustalls (Wiedenfeld and McAndrew 1968). The elevation of the station is $730 \mathrm{~m}$. The mean frost free period is $240 \mathrm{~d}$. Precipitation is highly variable within and among years (median annual precipitation $=557 \mathrm{~mm}$, range $=156-1054 \mathrm{~mm}$; station data records from 1919 to 2007). Precipitation is bimodal, usually occurring from intense, short-duration thunderstorms in the spring and autumn, interspersed with frequent, prolonged drought events. Plant communities include oak savanna, dominated by small clusters of live oak (Quercus virginiana Mill.) and pungent oak (Q. pungens Liebm.), and closed-canopy juniper woodland consisting of Ashe juniper and Pinchot's juniper, depending on management history (Kuchler 1964; Hatch et al. 1990; Fuhlendorf and Smeins 1998). Herbaceous vegetation is dominated by common curly mesquite (Hilaria belangeri [Steud.] Nash), Wright's threeawn (Aristida wrightii Nash), sideoats grama (Bouteloua curtipendula [Michx.] Torr.), hairy grama (B. hirsuta Lag.), Texas wintergrass (Nassella leucotricha [Trin. \& Rupr.] Pohl), Texas cupgrass (Eriochloa sericea [Scheele] Munro ex Vasey), and, to a lesser extent, little bluestem (Schizachyrium scoparium [Michx.] Nash).

A 12-ha portion of the station was fenced in 1994 to implement a long-term fire study. This section was chosen because it was one of the most homogenous units on the station. The area was characterized by similar soils, flat topography, consistent grazing and brush management history, and similar vegetation patterns (i.e., oak savanna). Sheep, goats, and cattle were removed from the unit prior to this experiment and all livestock were excluded for the duration of this study.

Six experimental units of equal area ( 2 ha) were established in the 12-ha section. Each unit was randomly assigned a longterm seasonal burn treatment of repeated summer burn, repeated winter burn, or nonburned control. Fire treatments were repeated every $6 \mathrm{yr}$, on average, to match the estimated historical mean fire frequency of this region (Frost 1998) while allowing enough flexibility to conduct high-intensity fires by skipping burns scheduled during seasons of high precipitation or to burn sooner than scheduled if ideal conditions became available. Summer burn units were burned in August 1994, July 2000, and July 2006. Winter burn units were burned in January 1996, January 2000, and February 2006. Each unit was burned independently.

Fire treatments were conducted during periods of belowaverage precipitation. Mean annual precipitation was $611 \pm$ $93 \mathrm{~mm}$ from 1994 to 2006; maximum and minimum annual precipitation were $837 \mathrm{~mm}$ in 2004 and 524 in 1999, respectively. Total precipitation for the second summer burn 
was approximately $18 \mathrm{~mm}$ during July through September $2000,90 \%$ less than the long-term average of $187 \mathrm{~mm}$ and marking the second most severe drought (according to Palmer Drought Severity Index; Palmer 1965) since the establishment of the Sonora Research Station (ca. 1919). Total precipitation was $114 \mathrm{~mm}$ and $187 \mathrm{~mm}$ in July through September for the other two summer burns conducted in 1994 and 2006. Total precipitation was also less than the long-term average of $79 \mathrm{~mm}$ when the winter burn treatments were conducted. Precipitation levels during the months of December through February were $13 \%, 26 \%$, and $84 \%$ of the long-term average for the 1996 , 2000, and 2006 winter burns, respectively.

\section{Vegetation Sampling}

The frequency of occurrence of graminoid species, woody plant species, and prickly pear cactus were sampled in each experimental unit along 10 randomly established and permanently marked 50-m transects. Prior to fire treatment in 1994, and again in 2006 , a $0.25-\mathrm{m}^{2}$ quadrat was placed at $2-\mathrm{m}$ increments along each transect to record the three most abundant graminoid species according to canopy cover. Frequencies of occurrence of each woody plant species and prickly pear cactus were measured along the transects in the overstory $(\geq 1.5 \mathrm{~m})$ and understory $(<1.5 \mathrm{~m})$. In 2006, total woody canopy cover was measured using the line intercept method (Floyd and Anderson 1987). A value of $0.10-\mathrm{m}$ was established a priori as the minimum amount of cover needed for an individual to count toward the frequency data and cover estimates. Gaps $<0.10 \mathrm{~m}$ in the canopy were ignored. Pretreatment woody plant canopy cover was not available for each transect; however, aerial photography showed total woody cover did not differ across the study site prior to this experiment.

\section{Data Analysis}

To test for differences in the overall plant community, data were analyzed using permutational multivariate analysis of variance (PERMANOVA; Anderson 2005). PERMANOVA is a useful tool that uses permutations to test hypotheses and calculate $P$ values in data from experimental designs that do not conform to assumptions of traditional one-way analysis of variance (ANOVA) or parametric multivariate analysis of variance (MANOVA). A key difference between these statistical techniques is that PERMANOVA only assumes that the observation units are exchangeable (i.e., observation units are independent), whereas ANOVA and MANOVA assume independent observations, normally distributed residuals, equality of variances, and additive treatment effects (Anderson 2001; Hinkelmann and Kempthorne 2008). PERMANOVA is designed to analyze ecological data, which commonly fail to conform to assumptions of normality; in addition, it avoids pseudo-replication in ecological designs with low replications (Anderson 2001; McArdle and Anderson 2001), such as this one $(n=2)$. In this study, PERMANOVA was performed on Bray-Curtis distances of $\ln (\mathrm{x}+1)$ transformed frequency data. Data were analyzed using burn treatment (repeat summer burns, repeat winter burns, and control) and height $(<1.5 \mathrm{~m}$ and $>1.5 \mathrm{~m}$, representing understory and overstory vegetation, respectively) as fixed factors. Data from 1994 and 2006 were analyzed separately because PERMANOVA should not be used to test for treatment $\times$ time interactions since data are autocorrelated in permanent plots that are repeatedly measured over time. Such was the case in this study. There are ways to account for autocorrelation to test for treatment $\times$ time interactions (e.g., Fule et al. 2005), but we did not use such techniques in this analysis due to the low replication of this design. $P$ values are based on Monte Carlo asymptotic permutation using 4999 runs; a Monte Carlo approach is appropriate when the experimental design lacks the number of observational units needed to obtain a reasonable number of permutations (Anderson and Robinson 2001; Anderson and Robinson 2003). Terms and interactions found to be significant in the full model were investigated using pair-wise comparisons where appropriate.

After testing for differences in the overall plant community, we separated the community data into grasses and woody plants to test hypotheses related to each functional group. Both groups were tested for pre-existing differences among assigned treatments in 1994 and for differences in 2006 resulting from burn treatments. In addition, the total canopy cover of woody plants in 2006 was tested for differences among burn treatments. Significant terms were evaluated using pair-wise comparisons where appropriate.

We performed canonical analysis of principal coordinates (CAP; Anderson and Willis 2003) to visualize differences in the plant community among treatments over time. CAP is a constrained ordination technique that accounts for the correlation structure among species, making it more appropriate than PERMANOVA or unconstrained ordination techniques (e.g., non-metric multidimensional scaling) when treatment groups differ in a direction of the multivariate space that is not strictly parallel with the direction of greatest overall variation (Anderson and Robinson 2003; Anderson and Willis 2003). Plant species that occurred in $<5 \%$ of all samples for both years were omitted to limit the effect of rare species and increase the ability to detect relationships between experimental treatments/environmental factors and changes in the plant community (McCune and Grace 2002).

\section{RESULTS}

\section{Plant Community}

Burn treatments altered the trajectory of the plant community from 1994 to 2006 relative to the control (Table 1). Repeatedly burning in the summer resulted in a woody plant community that differed from the control in 2006 while maintaining a similar grass community (Table 2). The winter burn treatment produced an overstory woody plant community that was similar to the overstory of the summer burn treatment, an understory woody plant community that was similar to the control, and a unique grass community (Table 2). Overall, burn treatments had the greatest effect on the overstory woody plant community, which changed more from 1994 to 2006 than woody plants and grasses in the understory (Fig. 1a, axis 2). Understory woody plant communities did not differ among treatments in 2006 (Table 2), but increases in the frequency of Ashe juniper and other species commonly associated with the overstory plant community (e.g., Pinchot's juniper, honey 
Table 1. Permutational multivariate analysis of variance results of tests for differences in the frequency of woody plants and grasses among burn treatments, between sampling heights, and for their interaction for each plant community functional group in 1994 and 2006.

\begin{tabular}{|c|c|c|c|c|c|c|c|}
\hline \multirow[b]{2}{*}{ Source } & \multirow[b]{2}{*}{ df } & \multicolumn{3}{|c|}{1994} & \multicolumn{3}{|c|}{2006} \\
\hline & & MS & $F$ & $P$ & MS & $F$ & $P^{1}$ \\
\hline \multicolumn{8}{|l|}{ All plants } \\
\hline $\mathrm{T}$ & 2 & 672 & 2.48 & 0.1262 & 1230 & 12.38 & 0.0016 \\
\hline $\mathrm{H}$ & 1 & 18391 & 67.93 & 0.0002 & 17465 & 175.89 & 0.0002 \\
\hline $\mathrm{T} \times \mathrm{H}$ & 2 & 129 & 0.48 & 0.6900 & 209 & 2.10 & 0.1614 \\
\hline Residual & 6 & 271 & & & 99 & & \\
\hline Total & 11 & & & & & & \\
\hline \multicolumn{8}{|c|}{ Woody plants } \\
\hline $\mathrm{T}$ & 2 & 1032 & 2.05 & 0.1490 & 1779 & 8.66 & 0.0014 \\
\hline $\mathrm{H}$ & 1 & 6898 & 13.69 & 0.0014 & 6265 & 30.50 & 0.0002 \\
\hline $\mathrm{T} \times \mathrm{H}$ & 2 & 142 & 0.28 & 0.8848 & 207 & 1.01 & 0.4324 \\
\hline Residual & 6 & 504 & & & 205 & & \\
\hline Total & 11 & & & & & & \\
\hline \multicolumn{8}{|l|}{ Grasses } \\
\hline $\mathrm{T}$ & 2 & 91 & 4.38 & 0.0618 & 6719 & 322.91 & 0.0002 \\
\hline Residual & 3 & 21 & & & 21 & & \\
\hline Total & 5 & & & & & & \\
\hline
\end{tabular}

${ }^{1}$ Bold $P$ values indicate statistically significant results $(P<0.05)$

${ }^{2} \mathrm{~T}$ indicates treatment; $\mathrm{H}$, height.

mesquite) caused the understory of the control treatment to shift away from pretreatment levels (Fig. 1, axis 1).

The only difference prior to treatment in 1994 was the presence of distinct plant communities in the overstory and the understory (Table 1). Differences between understory and overstory layers continued in 2006 (Table 1) and explained the greatest amount of variation in this plant community (Fig. 1a, axis 1). Such a finding was expected since savanna ecosystems typically feature a codominance of unique understory and overstory plant species. In general, live oak and Ashe juniper dominated the overstory, whereas Texas persimmon (Diospyros texana Scheele), prickly pear cactus, sacahuista, and algerita (Mahonia trifoliolata [Moric.] Fedde) were almost exclusively understory species (Fig. 1, axis 1). Pinchot's juniper and honey mesquite occurred in relatively similar proportions in the overstory and understory (Fig. 1, axis 1).

\section{Woody Plants and Cactus}

Woody plants and cactus increased from 1994 to 2006 in the overstory and understory of the control treatment. Live oak increased in the overstory of the control more than any other woody plant species (Table 3 ). Ashe juniper was approximately six times more frequent in the understory and overstory of the control in 2006 than in 1994 (Table 3). Pinchot's juniper, which was not found in control units in 1994, was present in the understory and overstory in 2006 (Table 3). Mesquite was also found in the overstory in 2006 after being absent from the overstory prior to treatment (Table 3). As a result, the overstory plant community of the control was converted from a live oak dominated overstory to a live oak-Ashe juniper dominated overstory interspersed with Pinchot's juniper and mesquite (Fig. 2). Similar trends were observed in the understory of the control. All species except algerita increased in the understory (Table 3 ).

Table 2. Pair-wise comparisons of differences in the frequency of species in each functional group between summer burn (SB), winter burn (WB), and control (C) treatments in 2006.

\begin{tabular}{|c|c|c|c|c|}
\hline Source & Statistic & SB vs. WB & SB vs. C & WB vs. C \\
\hline \multicolumn{5}{|l|}{ All plants } \\
\hline \multirow[t]{2}{*}{ Understory } & $t$ & 1.93 & 2.01 & 1.88 \\
\hline & $P$ & 0.1152 & 0.1042 & 0.1074 \\
\hline \multirow[t]{2}{*}{ Overstory } & $t$ & 1.62 & 3.96 & 2.84 \\
\hline & $P$ & 0.1864 & $0.0308^{1}$ & 0.0480 \\
\hline \multirow[t]{2}{*}{ Woody plants } & $t$ & 0.92 & 2.14 & 1.21 \\
\hline & $P$ & 0.4420 & 0.0296 & 0.3438 \\
\hline \multirow[t]{2}{*}{ Grasses } & $t$ & 18.06 & 2.47 & 124.55 \\
\hline & $P$ & 0.0018 & 0.0864 & 0.0004 \\
\hline
\end{tabular}

${ }^{1}$ Bold $P$ values indicate statistically significant results $(P<0.05)$. 

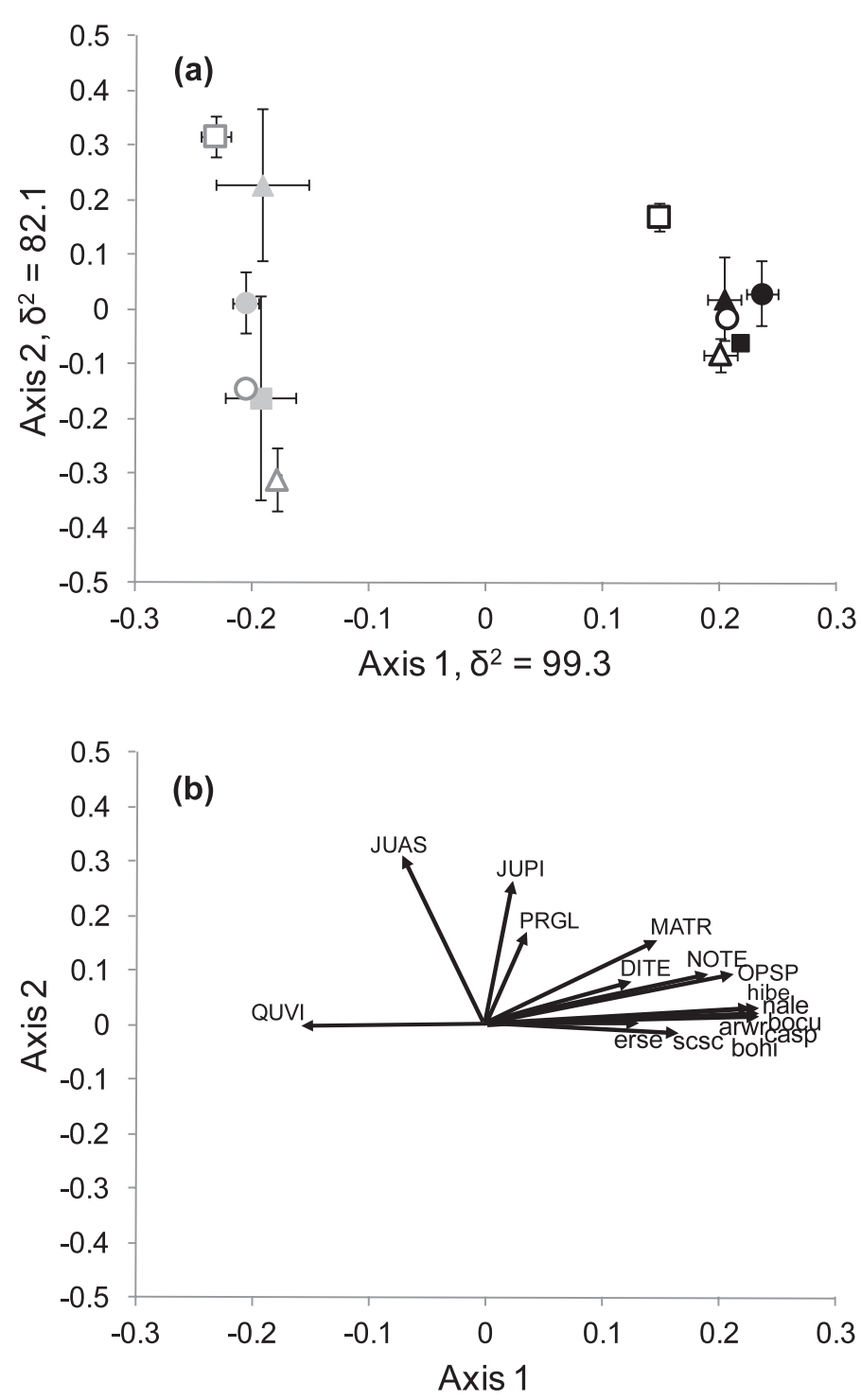

Figure 1. Canonical analysis of principal coordinates (CAP; a) of the plant community showing each combination of treatment, sampling height, and sampling year and the corresponding biplot (b) of all understory and overstory plant species. Symbols are as follows: shapes represent burn treatments of repeat summer burn (triangles), repeat winter burn (circles), and control (squares); colors represent sampling heights of $<1.5 \mathrm{~m}$ (black) and $\geq 1.5 \mathrm{~m}$ (gray); filled/open shapes represent sampling years of pretreatment in 1994 (filled) and posttreatment in 2006 (open). Data from CAP output were pooled for each replicate and shown here as means \pm SE. The biplot (b) shows woody species (capitalized) and grass species (lowercase); species acronyms are listed in Tables 3 and 5.

Repeatedly burning in the summer maintained the overall frequency of individuals and changed the presence of species in the woody plant community (Table 3), creating overstory and understory woody plant communities that differed from the control in 2006 (Figs. 2a and 2b). Sacahuista and Ashe juniper were no longer present in the understory of the summer burn treatment in 2006 (Table 3; Fig. 2d). The overstory (Fig. 2a) consisted almost exclusively of live oak in 2006 due to the complete removal of Ashe juniper and the conversion of other overstory woody plants to the understory (Table 3; Fig. 2).
Honey mesquite was the only other woody plant species that remained in the overstory in 2006 and it remained at low frequencies (Table 3 ).

The winter burn treatment generally maintained the number of species present in the understory and overstory but not the frequency of individuals. Burning in the winter maintained a live oak dominated overstory plant community over time (Fig. 2a) by preventing Ashe juniper from becoming a dominant component of the overstory (Fig. 2c; Table 3). However, unlike the summer burn treatment, repeatedly burning in the winter did not maintain the overall frequency of woody plants in the overstory due to large increases in live oak (Table 3). In contrast to the overstory plant community, the understory community of the winter burn treatment was more similar to the control than the summer burn treatment (Fig. 2b, axis 1). Like the control, the overall frequency of woody plant individuals increased over time in the understory of the winter burn treatment (Table 3). Species that increased most in the winter burn and control treatments were live oak, prickly pear cactus, and sacahuista (Table 3). The primary differences between the two understory plant communities was that Ashe juniper increased in the control treatment, whereas it was essentially removed in the winter burn treatment, live oak increased considerably more in the winter burn treatment, and prickly pear cactus increased considerably more in the control (Table 3).

Changes in the frequency of individual woody plants in the understory and overstory led to differences in the total cover of woody plants among treatments in 2006 (Table 4). Total woody cover was $18.2 \pm 1.3 \%$ of the transect length in the summer burn treatment and was significantly less than the $44.0 \pm 1.2 \%$ cover in the control; woody cover in the winter burn treatment was $38.2 \pm 0.7 \%$ and did not differ from summer burn or control treatments.

\section{Grasses}

The frequencies of occurrence of the most abundant grasses were primarily influenced by changes occurring over time (Fig. 3a, axis 1) and pre-existing variation within and among treatment units (Fig. 3a, axis 2). Consequently, fire was not the primary driver of the observed differences in the grass community among treatments in 2006. Each grass species, except little bluestem, responded consistently across all treatments (Table 5). Grass species that increased from 1994 to 2006 (Table 5) were negatively correlated with CAP axis 1 across treatments (Fig. 3b), whereas grass species correlated positively with axis 1 (Fig. 3b) decreased over time (Table 5). Little bluestem was weakly correlated with axis $1(r=0.04)$, increased in the winter burn treatment, remained fairly constant in the summer burn treatment, and decreased in the control (Table 5). Moreover, species that occurred the most in a given treatment at the beginning of the study continued to occur with greatest frequency in the same treatment in 2006 (e.g., the frequency of little bluestem occurrence was the most in the winter burn treatment in 1994 and 2006). This legacy effect is shown by CAP axis 2 (Fig. 3). Grass species strongly and positively correlated with axis 2 (Fig. 3b) occurred more frequently in 1994 and 2006 in the winter burn treatment than in the summer burn or control (Fig. 3a). Species negatively correlated with axis 2 (Fig. 3b) occurred more frequently in the summer burn treatment in 1994 than in the winter burn or control (Fig. 3a). Only common curly 
Table 3. Frequency of occurrence of each woody plant and cactus species in the understory $(\mathrm{U})$ and overstory $(0)$ of repeat summer burn (SB), repeat winter burn (WB), and control (C) treatments in 2006. Values are means \pm SE (and mean change from 1994 to 2006).

\begin{tabular}{|c|c|c|c|c|c|c|c|}
\hline \multirow[b]{2}{*}{ Woody species } & \multirow[b]{2}{*}{ Acronym } & \multicolumn{2}{|c|}{ SB } & \multicolumn{2}{|c|}{ WB } & \multicolumn{2}{|c|}{ C } \\
\hline & & U & 0 & U & 0 & U & 0 \\
\hline Live oak & QUVI & $28+12(+18)$ & $44+2(+14)$ & $68+9(+41)$ & $28+2(+24)$ & $2+5(+12)$ & $69+8(+47)$ \\
\hline Texas persimmon & DITE & $5+1(+5)$ & $0(-2)$ & $0(-3)$ & $6+2(+1)$ & $3+2(+1)$ & $1+1(-1)$ \\
\hline Ashe juniper & JUAS & $0(-3)$ & $0(-7)$ & $1+1(-3)$ & $1+1(-2)$ & $9+3(+8)$ & $23+6(+19)$ \\
\hline Pinchot's juniper & JUPI & $3+2(-1)$ & $0(-4)$ & $0(-1)$ & $2+1(+2)$ & $4+2(+4)$ & $6+2(+6)$ \\
\hline Honey mesquite & PRGL & $3+3(0)$ & $1+1(-3)$ & $1+1(+1)$ & $1+1(+1)$ & $4+1(+2)$ & $4+2(+4)$ \\
\hline Prickly pear & OPSP & $5+3(-5)$ & $0(-4)$ & $0(0)$ & $15+3(+6)$ & $32+6(+20)$ & $0(0)$ \\
\hline Sacahuista & NOTE & $0(-11)$ & $0(-2)$ & $0(0)$ & $22+16(+6)$ & $21+10(+11)$ & $0(0)$ \\
\hline Algerita & MATR & $1+1(-1)$ & $0(-1)$ & $0(-1)$ & $6+4(0)$ & $4+1(-1)$ & $3+3(+3)$ \\
\hline Total mean change & & +4 & -7 & +35 & +37 & +56 & +77 \\
\hline
\end{tabular}

mesquite broke this pattern in 2006, becoming more frequent in the control (Table 5). Other grass species continued to occur more frequently in the summer burn treatment.

\section{DISCUSSION}

\section{Woody Plant and Cactus Community}

Burning in the summer was the only treatment with less woody plant cover than the control and maintained the overall frequency of woody plants from 1994 to 2006, suggesting high intensity fires are needed to maintain semiarid live oak savanna. One potential consequence of applying high intensity fires is that overstory woody plants will be eliminated, causing the savanna to transition to grassland (Higgins et al. 2000) or to an understory-dominant community featuring resprouting woody plants. The propensity for some individuals in this live oak savanna to escape or limit fire-induced damage is likely associated with the Oskar-Gulliver hypothesis and spatial variation in fire intensity. The Oskar-Gulliver hypothesis
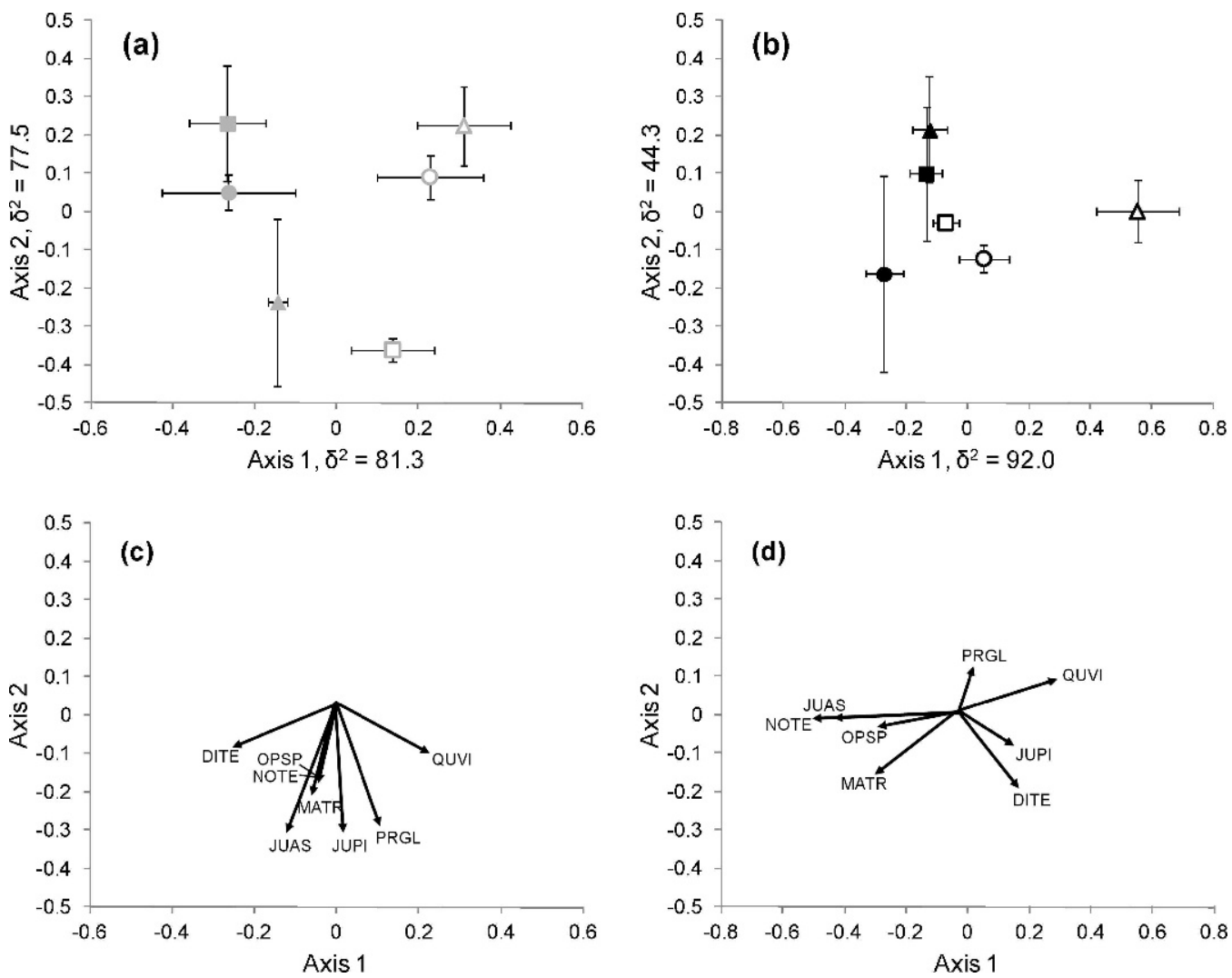

Figure 2. Canonical analysis of principal coordinates (CAP; a) of the overstory woody plant and (b) understory woody plant communities showing each combination of treatment and sampling year and the corresponding biplots of (c) overstory and (d) understory species. Symbols are as follows: shapes represent burn treatments of repeat summer burn (triangles), repeat winter burn (circles), and control (squares); filled/open shapes represent sampling years of pretreatment in 1994 (filled) and post-treatment in 2006 (open). Data from CAP output were pooled for each replicate and shown here as means + SE. Species acronyms are listed in Table 3. 
Table 4. PERMANOVA investigating differences in the total cover of woody plants among fire treatments in 2006 and the subsequent pairwise comparisons between summer burn (SB), winter burn (WB), and control (C) treatments.

\begin{tabular}{lrrcc}
\hline Source & df & MS & $F$ & $P^{1}$ \\
\hline Treatment & 2 & 91 & 11.98 & $\mathbf{0 . 0 2 6 8}$ \\
Residual & 3 & 7 & & \\
Total & 5 & & & \\
*Pair-wise comparisons & & $t$ & $P$ \\
\hline \multicolumn{2}{r}{ SB vs. WB } & & 1.83 & 0.1582 \\
\multicolumn{2}{l}{ SB vs. C } & & 4.02 & $\mathbf{0 . 0 4 2 0}$ \\
WB vs. C & & 2.66 & 0.0838 \\
\hline
\end{tabular}

${ }^{1}$ Bold $P$ values indicate statistically significant results $(P<0.05)$.

(Bond and van Wilgen 1996; Higgins et al. 2007) states that some individuals in savanna are old but kept small by fire (Oskar syndrome) and others have the potential to become giants once they escape fire (Gulliver syndrome). Live oak, the tallest tree at this site, was the primary species to have some individuals escape fires and become "giants," whereas other individuals of live oak, as well as Texas persimmon, Pinchot's juniper, and honey mesquite, were kept small or reduced from overstory to understory plants.

An individual occurring as an overstory vs. understory plant in this system is expected to be primarily a function of spatial variation in fire intensity. Fine-scale variation in grass fuels has been shown to drive spatial variation in fire intensity and lead to differential responses of individual woody plants in this system (Twidwell et al. 2009). Spatial variation in fire intensity and fire effects can result from localized variability in grass moisture content (Knapp and Keeley 2006), fine fuel load (Thaxton and Platt 2006; Twidwell et al. 2009), and tree-grass interactions (Slocum et al. 2003), among other factors. The combination of live oak being the tallest tree and influencing surrounding surface fuels likely explains why live oak was able to escape or limit the negative effects of fire more than other species.

While an increase in live oak is generally viewed positively due to its high preference as browse forage by goats in this region (Taylor and Kothmann 1990) and aesthetic appeal (Kreuter et al. 2004), large populations of live oak are currently being crippled in Texas by Ceratocystis fagacearum, a fungal pathogen that causes oak wilt (Appel 1995; Koch et al. 2010). An increase in the density and regeneration of live oak has led to highly interconnected root systems that facilitate the spread of oak wilt through common root systems and root grafts (Juzwik et al. 2008; Koch et al. 2010). Reducing current live oak densities or maintaining densities at presettlement levels is therefore a high priority (Koch et al. 2010). However, fire is not currently listed as a preventative strategy for oak wilt management. Combining the findings of this study with those conducted in savannas elsewhere (Trollope 1974; Holdo et al. 2009; Staver et al. 2009) suggests a combination of highintensity fires and livestock browsing is more likely to provide an effective means of maintaining overstory and understory densities at desired levels.

The exclusion of fire has led to encroachment of overstorydominant plants in the understory of the control and reveals
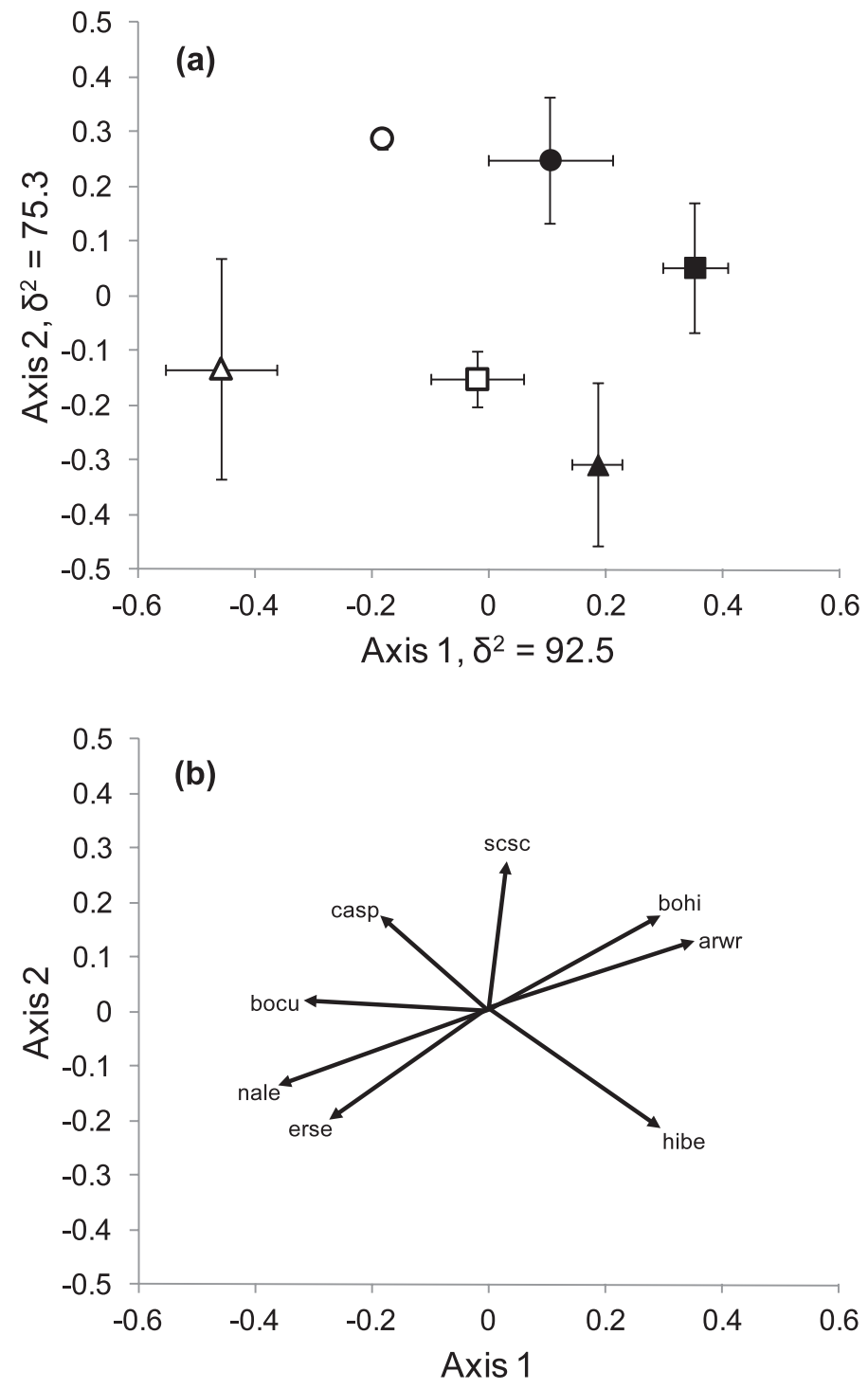

Figure 3. Canonical analysis of principal coordinates (CAP; a) of the grass community showing each combination of treatment and sampling year and the corresponding biplot (b) of grass species. Symbols are as follows: shapes represent burn treatments of repeat summer burn (triangles), repeat winter burn (circles), and control (squares); filled/ unfilled shapes represent sampling years of pretreatment in 1994 (filled) and post-treatment in 2006 (hollow). Data from CAP output were pooled for each replicate and shown here as means + SE. Species acronyms are listed in Table 5.

this system is on the verge of a regime shift from live oak savanna to live oak-juniper dominated woodland after only $12 \mathrm{yr}$. This result supports earlier simulations of the Edwards Plateau region (Fuhlendorf et al. 1996) that suggests grass-tree codominance will be lost after $20 \mathrm{yr}$ of fire exclusion. The continued absence of fire eventually produces a closed canopy Ashe juniper woodland interspersed with dense clusters of prickly pear cactus and little to no herbaceous surface fuels (Van Auken 2000) within 75 yr (Fuhlendorf et al. 1996). Such ecosystems are extraordinarily resilient to fire (Van Auken 2000), but restoration may be possible if high intensity fires are conducted during periods of drought (Twidwell et al. 2009). 
Table 5. Frequency each grass species was one of the three most abundant grasses in a sample in repeat summer burn (SB), repeat winter burn (WB), and control (C) treatments in 2006. Values are percent means \pm SE (and percent mean change from 1994 to 2006).

\begin{tabular}{|c|c|c|c|c|}
\hline Grass species & Acronym & SB & WB & C \\
\hline Sideoats grama & BOCU & $35 \pm 6(+7)$ & $35 \pm 1(+12)$ & $16 \pm 3(+7)$ \\
\hline Sedge spp. & CASP & $17 \pm 2(+5)$ & $26 \pm 1(+8)$ & $26 \pm 7(+11)$ \\
\hline Texas cupgrass & ERSE & $3 \pm 3(+2)$ & $1 \pm 0(+1)$ & $1 \pm 0(+1)$ \\
\hline Texas wintergrass & NALE & $56 \pm 4(+15)$ & $46 \pm 3(+14)$ & $50 \pm 2(+13)$ \\
\hline Wright's threeawn & ARWR & $8 \pm 2(-22)$ & $26 \pm 2(-4)$ & $20 \pm 3(-18)$ \\
\hline Hairy grama & $\mathrm{BOHI}$ & $3 \pm 0(-11)$ & $23 \pm 1(-21)$ & $8 \pm 2(-11)$ \\
\hline Common curly mesquite & HIBE & $52 \pm 3(-16)$ & $46 \pm 4(-8)$ & $56 \pm 4(-4)$ \\
\hline Little bluestem & $\operatorname{scsc}$ & $1 \pm 1(+1)$ & $11 \pm 0(+4)$ & $1 \pm 1(-3)$ \\
\hline
\end{tabular}

\section{Grass Community}

In contrast to the woody plant response, fire treatments did not explain the observed variability of the most frequently occurring grasses in this study. The greatest amounts of variation in these data were explained by changes occurring over time and legacy effects resulting from pre-existing variability. As a result, changes from 1994 to 2006 were consistent across treatments for all grass species except little bluestem. Similar to our findings, a previous livestock exclosure experiment at the Sonora Research Station showed sideoats grama and Texas cupgrass increased in basal area and dominance after a severe drought in the 1950s, whereas common curly mesquite and Wright's threeawn sharply decreased in basal area and dominance (Smeins et al. 1976). Livestock herbivory and precipitation variability, including the occurrence of the second most severe, prolonged drought in the history of the research station (Palmer Drought Severity Index $\leq-4$, 2000; Station Records 1919-2006), therefore played a larger role in shaping the grass community over this time period than whether sites were burned repeatedly in the summer, winter, or excluded from fire.

Researchers conducting grazing studies have long been aware that interannual variability in rainfall can mask the influence of grazing on the direction of vegetation change (Westoby 1980; O'Connor and Roux 1995) and have subsequently emphasized the use of long-term data sets (e.g., Milchunas et al. 1989; O'Connor 1994; Allen et al. 1995; O'Connor and Roux 1995; Fuhlendorf et al. 1997; Biondini et al. 1998; Fuhlendorf et al. 2001) and technology (e.g., remote sensing) to determine whether grazing or drought is a more dominant driver of longterm vegetation change (Walker 1988; Fuhlendorf et al. 2008). A 40+ yr grazing manipulation in this live oak savanna showed grazing intensity drove the long-term direction of herbaceous vegetation change, whereas annual variability in precipitation explained the short-term rate and direction of change (Fuhlendorf and Smeins 1997; Fuhlendorf et al. 2001). As a result of the 12-yr sampling interval and duration of this study, we were unable to detect if short-term oscillations occurred or if drought masked a long-term, fire-driven influence on the grass community. Few other long-term semiarid experiments have established the contributions of fire relative to grazing and climatic variability or their influence on short-term vs. longterm change. For those that exist, grazing has been shown to be a more dominant long-term driver than fire (Belsky 1992), and climatic variability has been shown to be more dominant than fire and grazing (Savadogo et al. 2008). We are unaware of a single long-term study that shows fire, not grazing or climatic variability, is a more dominant source of long-term change of grasses in native, semiarid rangelands. The limited number of long-term studies investigating this topic makes it difficult to determine how fire, herbivory, and climate interact to influence herbaceous vegetation change in semiarid environments over various temporal scales.

\section{MANAGEMENT IMPLICATIONS}

Managers and scientists have long questioned the merits of burning in rangelands. A couple of unresolved ecological issues have been at the forefront of managerial concerns in semiarid live oak savanna and were addressed in this experiment. One of the prevailing concerns historically is that fire will kill grass and degrade rangelands over time (e.g., Wright and Klemmedson 1965). This long-term fire experiment provides evidence to suggest that conducting high intensity fires in the summer during periods of below-average precipitation, when C4 grasses desired by managers are stressed, can reduce or eliminate woody plant species that threaten the stability of live oak savannas while having little long-term effect on the occurrence of the most abundant grasses. However, many managers want to protect mature live oak trees and are concerned that high intensity fires will top-kill those individuals (Olenick et al. 2004). The downside of not burning or only burning in milder fuel and fire weather conditions is that the number of live oak trees will increase, which may make the population more susceptible to oak wilt. Only high intensity fires conducted in the summer maintained the frequency of woody plants in this study after $12 \mathrm{yr}$ and slowed the increasing numbers of live oak compared to the control. While some individual trees were topkilled with high intensity fires, many trees escaped fire and maintained the aesthetic appeal of an overstory live oak savanna.

It is important for rangeland managers to be aware of the knowledge gaps that still need to be addressed by further scientific research. The 12 -yr time span between sampling dates does not allow us to provide information on whether most of the change in the woody plant community occurs after the first high intensity fire or subsequent fires. The specific fire intensity required to kill nonresprouting trees or alter the structure of resprouting species is unknown. It is also unclear how the treatments imposed in this study influence total herbaceous biomass, the productivity of individual grass species, 
herbaceous species diversity, and important minor grass species. Answers to these knowledge gaps will help rangeland managers more flexibly use high intensity fires in drought conditions to target problematic woody plant species while understanding the short-term and long-term impacts on the herbaceous community.

\section{ACKNOWLEDGMENTS}

We thank Lance Vermeire, Samuel Fuhlendorf, Tom Olszewski, William Rogers, and three anonymous reviewers for their reviews and contributions to this article. We also thank the technical assistance of workers and students at the Texas AgriLife Research Center in Sonora.

\section{LITERATURE CITED}

Allen, R. B., J. B. Wilson, and C. R. Mason. 1995. Vegetation change following exclusion of grazing animals in depleted grassland, Central Otago, New Zealand. Journal of Vegetation Science 6:615-626.

Anderson, M. J. 2001. A new method for non-parametric multivariate analysis of variance. Austral Ecology 26:32-46.

ANDERSON, M. J. 2005. PERMANOVA: a FORTRAN computer program to calculate a distance-based multivariate analysis for a linear model. Auckland, New Zealand: Department of Statistics, University of Auckland, New Zealand. 24 p.

Anderson, M. J., And J. Robinson. 2001. Permutation tests for linear models. Australian and New Zealand Journal of Statistics 43:75-88.

Anderson, M. J., AND J. Robinson. 2003. Generalised discriminant analysis based on distances. Australian and New Zealand Journal of Statistics 45:301-318.

Anderson, M. J., AND T. J. Willis. 2003. Canonical analysis of principal coordinates: a useful method of constrained ordination for ecology. Ecology 84:511-525.

Appel, D. N. 1995. The oak wilt enigma: perspectives from Texas. Annual Review of Phytopathology 33:103-118.

ARCHER, S. 1995. Tree-grass dynamics in a Prosopsis-thorn scrub savanna parkland: reconstructing the past and predicting the future. Ecoscience 2:83-99.

Archer, S., C. J. Scifres, C. R. Bassham, and R. Maggio. 1988. Autogenic succession in a subtropical savanna: conversion of grassland to thorn woodland. Ecological Monographs 58:111-127.

Archibald, S., W. J. Bond, W. D. Stock, And D. H. K. Fairbanks. 2005. Shaping the landscape: fire-grazer interactions in an African savanna. Ecological Applications 15:96-109.

Bachelet, D., R. P. Neilson, J. M. Lenihan, and R. J. Drapek. 2001. Climate change effects on vegetation distribution and carbon budget in the United States. Ecosystems 4:164-185.

BelskY, A. J. 1992. Effects of grazing, competition, disturbance and fire on species composition and diversity in grassland communities. Journal of Vegetation Science 3:187-200.

Biondini, M. E., B. D. Patton, and P. E. Nyren. 1998. Grazing intensity and ecosystem processes in a northern mixed- grass prairie, USA. Ecological Applications 8:469-479.

Bond, W. J. 2008. What limits trees in $\mathrm{C}_{4}$ grasslands and savannas? Annual Review of Ecology, Evolution, and Systematics 39:641-659.

Bond, W. J., AND G. F. Midgley. 2001. A proposed $\mathrm{CO}_{2}$-controlled mechanism of woody plant invasion in grasslands and savannas. Global Change Biology 6:865-869.

Bond, W. J., G. F. Midgley, and F. I. Woodward. 2003. The importance of low atmospheric $\mathrm{CO}_{2}$ and fire in promoting the spread of grasslands and savannas. Global Change Biology 9:973-982.

Bond, W. J., And B. W. Van Wilgen. 1996. Fire and plants. London, United Kingdom: Chapman and Hall. $263 p$.

Briggs, J. M., A. K. Knapp, J. M. Blair, J. L. Heisler, G. A. Hoch, M. S. Lett, and J. K. McCarron. 2005. An ecosystem in transition: causes and consequences of the conversion of mesic grassland to shrubland. Bioscience 55:243-254.
Brook, B. W., and D. M. J. S. Bowman. 2006. Postcards from the past: charting the landscape-scale conversion of tropical Australian savanna to closed forest during the 20th century. Landscape Ecology 21:1253-1266.

Floyd, D. A., and J. E. Anderson. 1987. A comparison of three methods for estimating plant cover. Journal of Ecology 75:221-228.

Freeman, D. B. 1992. Prickly pear menace in eastern Australia 1880-1940. Geographical Review 82:413-429.

Frost, C. C. 1998. Presettlement fire frequency regimes of the United States: a first approximation. Tall Timbers Fire Ecology Conference Proceedings 20:70-81.

Fuhlendorf, S. D., S. R. Archer, F. E. Smeins, D. M. Engle, and C. A. Taylor, JR. 2008. The combined influence of grazing, fire, and herbaceous productivity on treegrass interactions. In: 0. W. Van Auken [ED.]. Western North American Juniperus communities: a dynamic vegetation type. New York, NY, USA: Springer-Verlag. p. 219-238.

Funlendorf, S. D., D. D. Briske, and F. E. Smeins. 2001. Herbaceous vegetation change in variable rangeland environments: the relative contribution of grazing and climatic variability. Applied Vegetation Science 4:177-188.

Fuhlendorf, S. D., and F. E. Smeins. 1997. Long-term vegetation dynamics mediated by herbivores, weather and fire in a Juniperus-Quercus savanna. Journal of Vegetation Science 8:819-828.

Funlendorf, S. D., And F. E. Smeins. 1998. The influence of soil depth on plant species response to grazing within a semiarid savanna. Plant Ecology 138:89-96.

Fuhlendorf, S. D., F. E. Smeins, and W. E. Grant. 1996. Simulation of a fire-sensitive ecological threshold: a case study of Ashe juniper on the Edwards Plateau of Texas, USA. Ecological Modelling 90:245-255.

Fule, P. Z., D. C. Laughlin, and W. W. Covington. 2005. Pine-oak forest dynamics five years after ecological restoration treatments, Arizona, USA. Forest Ecology and Management 218:129-145.

Hatch, S. L., K. N. Ghadi, And L. E. Brown. 1990. Checklist of the vascular plants of Texas. College Station, TX, USA: Texas Agricultural Experiment Station MP1655. $158 \mathrm{p}$

Higgins, S. I., W. J. Bond, E. C. February, A. Bronn, D. I. W. Euston-Brown, B. Enslin, N. Govender, L. Rademan, S. O’Regan, A. L. F. Potgieter, S. Scheiter, R. Sowry, L. Trollope, and W. S. W. Trollope. 2007. Effects of four decades of fire manipulation on woody vegetation structure in savanna. Ecology 88:1119-1125.

HigGINS, S. I., W. J. Bond, AND S. W. TRoLlope. 2000. Fire, resprouting and variability: a recipe for grass-tree coexistence in savanna. Journal of Ecology 88:213-229.

Hinkelmann, K., and 0. KempthoRne. 2008. Design and analysis of experiments: introduction to experimental design. Vol 1. New York, NY, USA: Wiley. $631 \mathrm{p}$.

Hobbs, R. J., and H. A. Mooney. 1986. Community changes following shrub invasion of grasslands. Oecologia 70:508-513.

Holdo, R. M., R. D. Holt, and J. M. Fryxell. 2009. Grazers, browsers, and fire influence the extent and spatial pattern of tree cover in the Serengeti. Ecological Applications 19:95-109.

JoHnson, P. S. 1993. Perspectives on the ecology and silviculture of oak dominated forests in the central and eastern states. US Department of Agriculture Forest Service, General Technical Report, NC-153. St. Paul, MN, USA: North Central Forest Experiment Station. $28 \mathrm{p}$.

Juzwik, J., T. C. Harrington, W. L. MacDonald, and D. N. Appel. 2008. The origin of Ceratocystis fagacearum, the oak wilt fungus. Annual Review of Phytopathology 46:13-26.

Knapp, E. E., and J. E. Keeley. 2006. Heterogeneity in fire severity within early season and late season prescribed burns in a mixed-conifer forest. International Journal of Wildland Fire 15:37-45.

Koch, K. A., G. L. Quiram, and R. C. Venette. 2010. A review of oak wilt management: a summary of treatment options and their efficacy. Urban Forestry and Urban Greening 9:1-8.

Kreuter, U. P., M. R. Tays, and J. R. Conner. 2004. Landowner willingness to participate in a Texas brush reduction program. Journal of Range Management 57:230-237.

KuchleR, A. W. 1964. Potential natural vegetation of the conterminous United States. New York, NY, USA: American Geographic Society. 116 p.

LotTeR, W. D., AND J. H. Hoffmann. 1998. Integrated management plan for the control of Opuntia stricta in the Kruger National Park. Koedoe 41:63-68. 
McArdle, B. H., And M. J. Anderson. 2001. Fitting multivariate models to community data: a comment on distance based redundancy analysis. Ecology 82:290-297.

McCune, B., and J. B. Grace. 2002. Analysis of ecological communities. Gleneden Beach, OR, USA: MjM Software Design. 304 p.

MerRilL, L. B., AND J. L. Schuster. 1978. Grazing management practices affect livestock losses from poisonous plants. Journal of Range Management 31:351-354.

Milchunas, D. G., W. K. Lauenroth, P. L. Chapman, and M. K. Kazempour. 1989. Effects of grazing, topography, and precipitation on the structure of a semiarid grassland. Vegetatio 80:11-23.

O'Connor, T. G. 1994. Composition and population responses of an African savanna grassland to rainfall and grazing. Journal of Applied Ecology 31:155-171

O'Connor, T. G., And P. W. Roux. 1995. Vegetation changes (1949-71) in a semiarid, grassy dwarf shrubland in the Karoo, South Africa: influence of rainfall variability and grazing by sheep. Journal of Applied Ecology 32:612-626.

Olenick, K. L., U. P. Kreuter, and J. R. Conner. 2004. Texas landowner perceptions regarding ecosystem services and cost-share land management programs. Ecological Economics 57:337-345.

PalmeR, W. C. 1965. Meteorological drought. Research paper no. 45. Washington, DC, USA: US Weather Bureau. 58 p.

Roques, K. G., T. G. O'Connor, and A. R. Watkinson. 2001. Dynamics of shrub encroachment in an African savanna: relative influences of fire and herbivory, rainfall and density dependence. Journal of Applied Ecology 38:268-280.

Sankaran, M., N. P. Hanan, R. J. Scholes, J. Ratnam, D. J. Augustine, B. S. Cade, J. Gignoux, S. I. Higgins, X. Le Roux, F. Ludwig, J. Ardo, F. Banyikwa, A. Bronn, G. Bucini, K. K. Caylor, M. B. Coughenour, A. Diouf, W. Ekaya, C. J. Feral, E. C. February, P. G. H. Frost, P. Hiernaux, H. Hrabar, K. L. Metzger, H. H. T. Prins, S. Ringrose, W. Sea, J. Tews, J. Worden, and N. Zambatis. 2005. Determinants of woody cover in African savannas. Nature 438:846-849.

Sankaran, M., J. Ratnam, and N. P. Hanan. 2004. Tree-grass coexistence in savannas revisited-insights from an examination of assumptions and mechanisms invoked in existing models. Ecology Letters 7:480-490.

Savadogo, P., D. Tiveau, L. Sawadogo, and M. Tigabu. 2008. Herbaceous species responses to long-term effects of prescribed fire, grazing and selective tree cutting in the savanna woodlands of West Africa. Perspectives in Plant Ecology, Evolution and Systematics 10:179-195.

Scholes, R. J., And S. R. ArCher. 1997. Tree-grass interactions in savannas. Annual Review of Ecology and Systematics 28:517-544.

Scholes, R. J., ANd B. H. Walker. 1993. An African savanna: synthesis of the Nylsvley Study. Cambridge, United Kingdom: Cambridge University Press. $320 \mathrm{p}$.
Silva, J. F., A. Zambrano, and M. R. Farinas. 2001. Increase in the woody component of seasonal savannas under different fire regimes in Calabozo, Venezuela. Journal of Biogeography 28:977-983.

Slocum, M. G., W. J. Platt, and H. C. Cooley. 2003. Effects of differences in prescribed fire regimes on patchiness and intensity of fires in subtropical savannas of Everglades National Park, Florida. Restoration Ecology 11:91-102.

Smeins, F. E., T. W. Taylor, and L. B. Merrill. 1976. Vegetation of a 25-year exclosure on the Edwards Plateau, Texas. Journal of Range Management 29:24-29.

Staver, A. C., W. J. Bond, W. D. Stock, S. J. van Rensburg, and M. S. Waldram. 2009. Browsing and fire interact to suppress tree density in an African savanna. Ecological Applications 19:1909-1919.

Taylor, C. A., and M. M. Kothmann. 1990. Diet composition of Angora goats in a short-duration grazing system. Journal of Range Management 43:123-126.

TAYloR, C. A., And M. H. Ralphs. 1992. Reducing livestock losses from poisonous plants through grazing management. Journal of Range Management 45:9-12.

Thaxton, J. M., AND W. J. PLATt. 2006. Small-scale fuel variation alters fire intensity and shrub abundance in a pine savanna. Ecology 87:1331-1337.

Trollope, W. S. W. 1974. The role of fire in preventing bush encroachment in the Eastern Cape. Proceedings of the Grassland Society of South Africa 9:67-72.

Trollope, W. S. W., F. O. Hobson, J. E. Danckwerts, and J. P. Van Niekerk. 1989. Encroachment and control of undesirable plants. In: J. E. Danckwerts and W. R. Teague [EDS.]. Veld management in the Eastern Cape. Pretoria, South Africa: Department of Agriculture and Water Supply. p. 73-89.

Twidwell, D., S. D. Fuhlendorf, D. M. Engle, and C. A. Taylor, JR. 2009. Surface fuel sampling strategies: linking fuel measurements and fire effects. Rangeland Ecology \& Management 62:223-229.

Van Auken, 0. W. 2000. Shrub invasions of North American semiarid grasslands. Annual Review of Ecology and Systematics 31:197-215.

Van Langevelde, F., C. van de Visver, L. Kumar, J. van de Koppel, N. de Ridder, J. van Andel, A. K. Skidmore, J. W. Hearne, L. Stroosnijder, W. J. Bond, H. H. T. Prins, AND M. RieTKERK. 2003. The effects of fire and herbivory on the stability of savanna ecosystems. Ecology 84:337-350.

Van Vegten, J. A. 1983. Thornbrush invasion in a savanna ecosystem in eastern Botswana. Vegetatio 56:3-7.

WaLKER, B. H. 1988. Autecology, synecology, climate and livestock as agents of rangeland dynamics. Australian Rangeland Journal 10:69-75.

WestoBy, M. 1980. Elements of a theory of vegetation dynamics in arid rangelands. Israel Journal of Botany 28:169-194.

Wiedenfeld, C. C., And J. D. McAndrew. 1968. Soil survey of Sutton County, Texas. Washington, DC, USA: Soil Conservation Service, US Government Printing Office. $33 \mathrm{p}$

Wright, H. A., and J. O. Klemmedson. 1965. Effect of fire on bunchgrasses of the sagebrush-grass region in southern Idaho. Ecology 46:680-688. 